American Journal of Environmental Sciences 6 (4): 324-328, 2010

ISSN 1553-345X

(C) 2010 Science Publications

\title{
Pollution Sources and Standards of Cashew Nut Processing
}

\author{
${ }^{1}$ Atul Mohod, ${ }^{2}$ Sudhir Jain and ${ }^{1}$ A.G. Powar \\ ${ }^{1}$ Department of Renewable Energy Sources, \\ College of Agriculture Engineering and Technology, Dapoli, Maharashtra, India \\ ${ }^{2}$ Department of Renewable Energy Sources, \\ College of Technology and Engineering, MPUAT, Udaipur, India
}

\begin{abstract}
Problem statement: India is largest producer, processor, exporter and second largest consumer of cashew in the world with annual production of 6,20,000 MT. India processed about 1.18 million MT of raw cashew seeds through 3650 cashew processing industries scattered in many states of country. The cashew industries employed different unit operations/ methodologies for processing depend on variety of raw material, location, technological mechanization and availability of secured energy supply. Approach: There are two commonly followed methods of cashew nut processing, viz., roasting process and steam (roasting) process. The sources of different environmental pollutant discharged in to the atmosphere during the cashew nut processing have been revealed in the article. Results: The environmental standards for air pollution emission for roasting process, steam cooking process and broma oven have been presented. The solid waste disposal practice and new and relocation sitting criteria have been discussed for cashew processing industries. Conclusion: The cashew nut processing by cooking (steam roasting) process, which is relatively less pollution intensive and an alternative process to roasting process may be considered to reduce the environmental discharge load.
\end{abstract}

Key words: Cashew, roasting, steam, pollution, source

\section{INTRODUCTION}

Cashewnutprocessing: Cashew (Anacardium Occidentale L.) is one of the important tropical crops called as “poor man's crop, rich man's food". The cashew nut is native of Brazil from where Portuguese travelers took the cashew tree to colonies in India, first recorded in Cochin by 1578, in Goa by 1598 (Smith et al., 1992). The crop is grown mainly in peninsular states of India particularly along the coastal states like Kerala, Karnataka, Goa, Maharashtra, Tamil Nadu Andhra Pradesh, Orissa and West Bengal. India processed about 1.18 million MT of raw cashew seeds through 3650 cashew processing industries scattered in many states of country provided employment to over 0.5 million people (Anonymous, 2008).

The cashew industry in India employed different unit operations/methodology for processing depends on variety of raw material, location, technological mechanization and availability of secured energy supply (Balsubramanian, 2006). There are two commonly followed methods of cashew nut processing, viz. Roasting process and steam cooking process. In cooking process vegetable oil is extracted from the cashew shell of the seeds, which has market in paint and adhesive industry. Due to lack of skilled manpower for cutting process of cooked nut and difference in taste of nut, many of the industries in India are following roasting process. In the cashew nut roasting process, thick black smoke is released from the rotating roasting drum through the stack. The smoke, when it reaches the ground, has irritating odor and is public nuisance in the neighborhood. Borma heater is also a source of air pollution. Wastewater is generated from the quenching operation of the roasted cashew nut discharged. Cooking process also discharges wastewater from the steam cooker and emits air pollutants by Baby Boiler for steam generation and Borma heater (Anonymous, 2006).

Since these industries are small and cottage category units and no conventional and technoeconomically cost effective pollution abatement systems are in operation elsewhere, it has become necessary to study the entire cashew nut processing industry sector in India to suggest techno-economically feasible environmental standards. Even though the pollution load from individual unit is relatively low, the magnitude of pollution problem from the cluster of units is very high.

Corresponding Author: Atul Mohod, Department of Renewable Energy Sources,

College of Agriculture Engineering and Technology, Dapoli, Maharashtra, India 


\section{MATERIALS AND METHODS}

The cashew nut processing industries in the rural area were studied for unit operations involved and the discharge of pollution for the processing industries were quantified.

The general processing steps involved in cashew processing are drying of freshly harvested raw seed for storage, Soaking of seed, Steam cooking or roasting, Shelling, Separation, Kernel drying, Peeling and Packaging (Balasubramanian, 2007). The general process flow chart for cashew processing adopted in India is shown in Fig. 1.

Drying of raw nuts: Sun dried in yards, weight loss may vary from $3 \%$ to over $10 \%$ depending on time of harvesting and area of origin. The raw nuts after harvest are sun dried for 2-3 days to reduce the moisture from $25-8-9 \%$ and stored in gunny bag. The raw cashew nut contains the kernel and study seed coat (testa); these account for $20-30$ and $2-3 \%$, respectively, of the raw nut weight; the remaining $70-75 \%$ is the shell.

\section{Roasting/steam cooking: Roasting:}

- Drum roasting: Nuts passed through heated drum where it catches fire for $2 / 3 \mathrm{~min}$

- Oil roasting: Dried nuts are conditioned with water passed through hot oil bath Cashew Nut Shell Liquid (CSNL) by using the conveyer

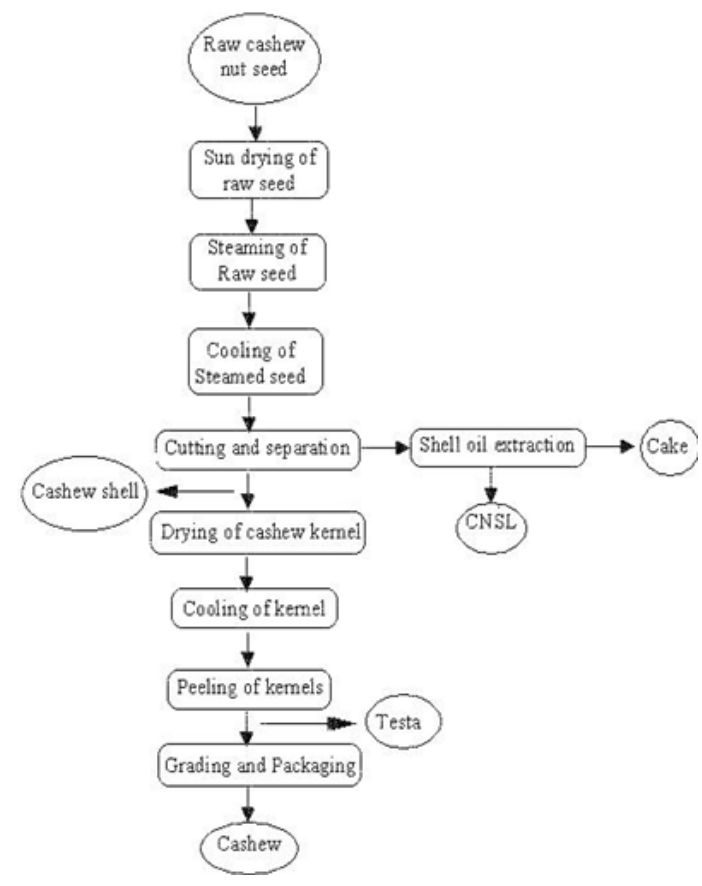

Fig. 1: Process flow chart for cashew nut processing
Steaming: This method now days adopted widely all over the India. The dried nuts are steam cooked. Welldried raw nuts are subjected for steam boiling, which is commonly, adopted method of nut conditioning in India. The raw nuts are steamed conditioned about $4.5-5 \mathrm{~kg} \mathrm{~cm}^{-2}$ steam pressure for 25-30 min and then allowed for 24 cooling in shed.

\section{Decordication:}

- Shelling: Roasted nuts have to be shelled by breaking shells with wooden mallets

- Cutting: Steamed nuts have to be cut with blades mounted on wooden tables. Raw nuts after conditioning and cooling are to be shelled to remove kernels with the help of hand cum pedal operated shell cutter. After shelling the kernels and shell pieces are separated manually

Drying of the kernels: The kernels are dried to moisture content about 3.5-4.5\%. Drying the kernel in hot chamber at $65-70^{\circ}$ centigrade in perforated tray for 6-8 h does this. After drying, the kernels are kept in moist chamber for 4-6 $\mathrm{h}$ for easy removal of testa and minimum broken kernel.

Peeling: The testa is peeled off and initial grading interm of wholes, pieces and broken are took place manually. The peeling process involved removal of testa from the kernel with the help of sharp knife.

Grading: The kernels are graded by hand/sieve. Cashew Export and Promotion Council (CEPC) specifications are adopted for grading of cashew kernels.

Filling: The graded kernels are:

- Vita packed in $100 \mathrm{~kg}$ tins-after vacuuming and infusing carbon dioxide

- Packed in 100 or $200 \mathrm{~kg}$ gas infused flexi packs

\section{Packing:}

- Two $100 \mathrm{~kg}$ tins are packed in a corrugated box

- Two 100 or $200 \mathrm{~kg}$ flexi pack sec ${ }^{-1}$ are packed in a corrugated box

\section{RESULTS AND DISCUSSION}

The different sources of environmental pollution from the cashew processing industries were identified. 
Sources of environmental pollution in cashew nut processing: The cashew nut processing is highly labor intensive, generally carried out during 0600-1800 h only during the day time.

Roasting process: The roasting of cashew seeds is carried out in a manually rotating open drum of diameter of $600 \mathrm{~mm}$ and $2.5 \mathrm{~m}$ length, with an inclination of axis $\left(15-20^{\circ}\right)$ to facilitate the flow of the material from inlet to outlet by rotation of the drum and gravity. The drum is placed in a 'dog-house'. Initially the drum is heated externally by firing about $25-30 \mathrm{~kg}$ of roasted cashew shell for about 15-20 min. Once the drum is heated up, the cashew nuts are fed manually through an elevated hopper into the inlet of the hot drum. The drum is rotated manually, so that the cashew nuts are moved from inlet to outlet of the drum. Due to the high temperature of the drum, the Cashew Nut Shell Liquid (CNSL) in the cashew nut catches the fire spontaneously and the nuts are roasted through the entire length of the drum without any supporting fuel. The hot gases from the inlet of the drum are discharge into atmosphere by a natural draft stack of about $15-18 \mathrm{~m}$ height. The cashew nuts, in burning state, are discharged at the outlet of the drum and quenched immediately with spray of water to prevent further roasting (Fig. 2). The water consumption by quenching process is in the range of $14-21 \mathrm{~L} / 100 \mathrm{~kg}$ of nut roasted. The ash generated from the drum during the initial firing with roasted shell is sprinkled on the wet nuts to prevent sticking. The quench water is collected in an oil trap and discharged on ground as wastewater. The water vapor and fumes generated while quenching are discharged by independent short vents connected to the dog-house. In some units, these vents are also connected to the main chimney.

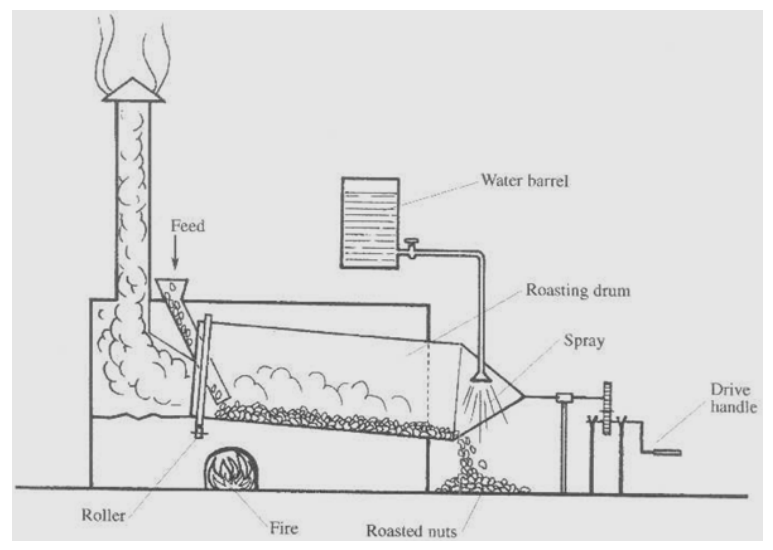

Fig. 2: Drum roaster for cashew nut roasting
The cooled nuts are sent for shelling. The manual feeding of the cashew nut and the rotation of the drum are so synchronized that about 6-7 bags (each bag weighs about $80 \mathrm{~kg}$ of cashew nut) of cashew nut are roasted in an hour.

Cooking (steam roasting) process: The steam roasting process, commonly known as "cooking process" consists of a baby boiler followed by a steam cooker where the cashew nuts are cooked with steam.

Baby boiler: The baby boiler is a hand stoked fire tube boiler, which produces steam at $4.5-5 \mathrm{~kg} \mathrm{~cm}^{-2}$. The roasted cashew shell or de-oiled cakes are fed manually (about 2-3 kg fuel once in 15-20 min) at the bottom of the boiler. The combustion air is drawn through the grate by natural draft stack at the top of the boiler. The flue gases from the boiler are discharged into atmosphere through the stack $12-15 \mathrm{~m}$ high. The flue gas emissions from the boiler are the source of air pollution.

Cashew nut cooker: A cylindrical steam cooker with provision of cashew nut feeding at the top and discharging of cooked nuts from the side near bottom, has a capacity of holding 4 bags ( $80 \mathrm{~kg}$ each) of cashew nut in a batch. Once the cashew nut is loaded, steam from a boiler is introduced into cooker at a pressure of $4.5-5 \mathrm{~kg} \mathrm{~cm}^{-2}$. The cashew nuts in the cooker are steam cooked and when all the nuts are sufficiently cooked, the excess steam starts releasing near the bottom outlet. The steam is injected into the cooker till the steam starts escaping form the outlet mouth of the cooker. This process takes about $10-20$ min time. Then the steam injection into the cooker is stopped and the condensed water at the bottom of the cooker is discharged in to a container and disposed on ground through septic tank. The cooked cashew nut are removed from the bottom of the cooker and spread on the floor for cooling. The cooled nuts are sent for cutting section to cut open and collect the kernel. The total batch time is about 4045 min. Usually, the units are provided with a baby boiler and minimum two cookers, while one cooker is in cooking operation, the other cooker is in unloading and loading operation. Normally the cooking operation is carried out for 2-4 h in a day, cooking 5-10 batches of nuts, depending on the production capacity of the units.

Kernel drying (broma): The kernel coming from the shelling section (Roasting Process) as well as Cutting Section (Cooking Process) contains a brown cover, known as 'testa', over it. To remove testa over the 
kernel and also control the moisture content in the kernels, they are exposed to prolonged and controlled heating with hot air at $60-70^{\circ} \mathrm{C}$ for about $6-7 \mathrm{~h}$ in the chamber. About $5-8 \%$ of moisture is removed from the kernels in the process. This process is known as "Borma". Indirect heating of atmospheric air generates the hot air over hot surface in a "Oven". The Borma ovens are fired with cashew shell (from Roasting Process) or de-oiled cashew cake (from Cooking Process) for about 4-6 h depending on the quantity of kernels to be dried (Fig. 3).

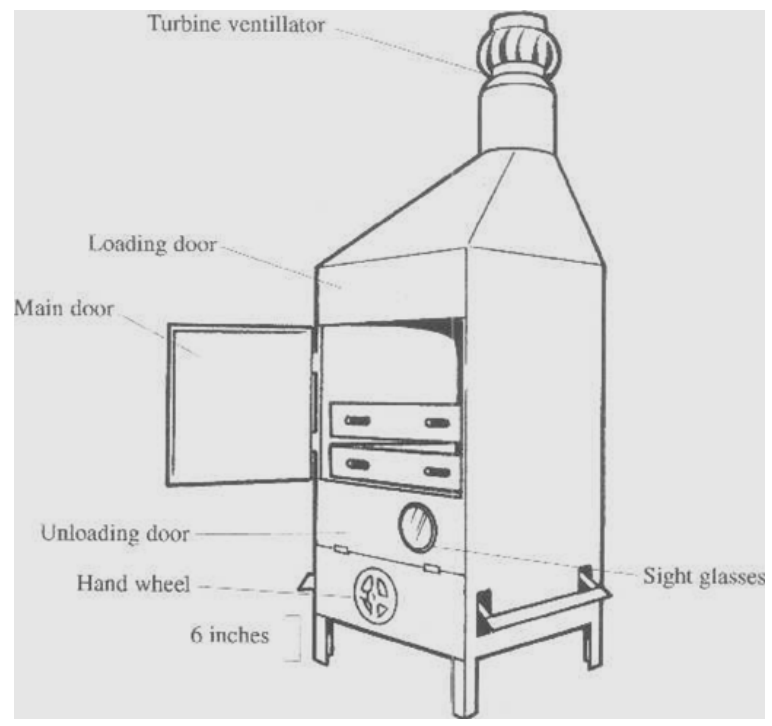

Fig. 3: Broma oven for cashew kernel drying

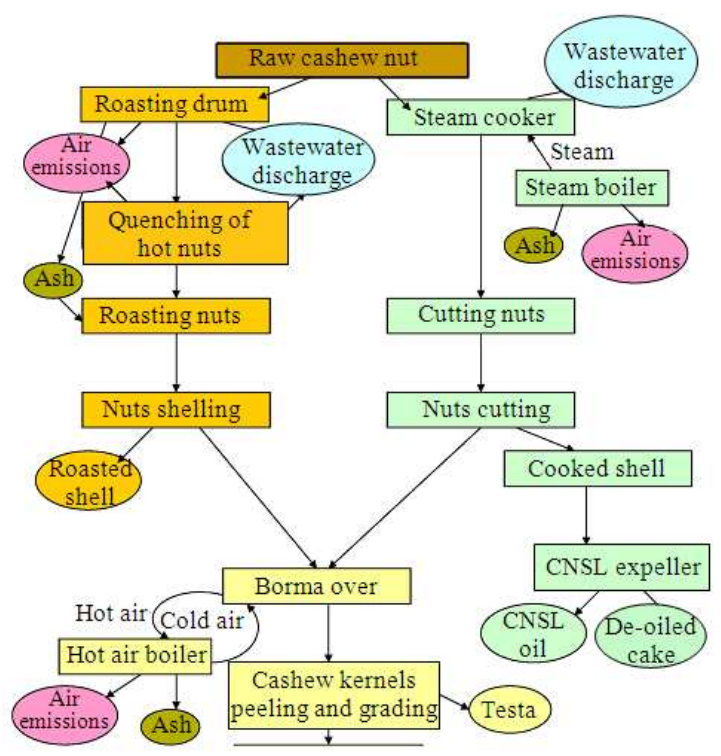

Fig. 4: Environment discharge through cashew nut processing
A natural draft stack of about 13-15 m high discharges the flue gases from the oven. In Kerala and Maharashtra most of the small-scale units carried out the Borma operation by electric heaters, which consume large electricity and the process will be dependent on power supply.

The process description and environmental pollution discharge is shown in Fig. 4.

Environmental standards for cashew processing industries: The environmental standards approved by the Peer and Core Committee of Central Pollution Control Board, India for the cashew Seed Industry are approved as follows.

Air pollution emission standards: The approved environmental standards for Roasting Process, Cooking Process and Borma operation of cashew processing are summarized in Table 1.

Sulphur dioxide, nitrogen oxides and phenolic compounds: The suggested stack heights results in better dispersion of these pollutants into atmosphere resulting in minimum possible ground level concentrations. Hence no separate emission standards are proposed for these parameters.

Wastewater discharge standards: The wastewater generation from different sources of cashew nut roasting and cooking process are as follows:

Quenching operation in roasting process: $200 \mathrm{~L} \mathrm{day}^{-1}$ (2-4 $\mathrm{h}$ of operation in a day)-after oil and grease trap

or

Vessel discharge from 5-10 batches in Cooking Process: 70-80 $\mathrm{L} \mathrm{day}^{-1}$

In view of such infrequent nature of wastewater generation and BOD of $5000 \mathrm{mg} \mathrm{L}^{-1}$, COD of $10000 \mathrm{~m} \mathrm{~L} \mathrm{~L}^{-1}$ and Oil and Grease (Extractable, mostly in the form of phenolics compounds) at $2000 \mathrm{mg} \mathrm{L}^{-1}$, the following alternatives are recommended to comply with following waste water discharge standards for disposal on land (Table 2).

\section{Solid waste disposal practices:}

- The use of cashew shell generated especially by roasting process, as fuel, has to go through bio gasification route to convert into less polluting fuel gas as a long-term measure 
Am. J. Environ. Sci., 6 (4): 324-328, 2010

Table 1: Air pollution standards for cashew processing

\begin{tabular}{|c|c|c|c|c|c|}
\hline \multirow[b]{2}{*}{ Parameter } & \multirow{2}{*}{$\begin{array}{l}\text { Roasting process } \\
\text { (2-4 h of operation and } 560-640 \mathrm{~kg} \\
\mathrm{~h} \text { of cashewnut processing) }\end{array}$} & \multicolumn{2}{|c|}{$\begin{array}{l}\text { Cooking process-steam boiler } \\
\text { ( } 4-6 \mathrm{~h} \text { of operation) }\end{array}$} & \multicolumn{2}{|c|}{ Borma oven heater ( $4-6 \mathrm{~h}$ of operation) } \\
\hline & & Roasted shell & De-oiled cake & Roasted shell & De-oiled cake \\
\hline $\begin{array}{l}\text { Particulate } \\
\text { Matter } \\
\text { Minimum } \\
\text { stack height } \\
\text { (m) }\end{array}$ & $\begin{array}{l}150 \mathrm{mg} \mathrm{Nm}^{-3} \\
\text { at } 4 \% \mathrm{CO}_{2} \\
20 \mathrm{~m} \text { from ground } \\
\text { level }\end{array}$ & $\begin{array}{l}150 \mathrm{mg} \mathrm{Nm}^{-3} \\
\text { at } 4 \% \mathrm{CO}_{2} \\
15 \mathrm{~m} \text { from gro } \\
\text { the height of th } \\
\text { which ever is }\end{array}$ & $\begin{array}{l}150 \mathrm{mg} / \mathrm{NM}^{3} \\
\text { at } 4 \% \mathrm{CO}_{2} \\
2 \mathrm{~m} \text { above } \\
\text { uilding, }\end{array}$ & $\begin{array}{l}150 \mathrm{mg} \mathrm{NM}^{-3} \\
\text { at } 4 \% \mathrm{CO}_{2} \\
\text { Minimum } \\
\text { stack height (m) }\end{array}$ & $\begin{array}{l}150 \mathrm{mg} \mathrm{NM}^{-3} \\
\text { at } 4 \% \mathrm{CO}_{2} \\
20 \mathrm{~m} \text { from } \\
\text { ground level }\end{array}$ \\
\hline
\end{tabular}

Table 2: Waste water discharge standards of cashew nut processing

\begin{tabular}{ll}
\hline Parameter & Limit $\left(\mathrm{mg} \mathrm{L}^{-1}\right)$ \\
\hline BOD $\left(27^{\circ} \mathrm{C}\right.$ and 3 days $)$ & 100 \\
Oil and grease & 10 \\
Suspended solids & 100 \\
Phenol & 1.0 \\
PH & $6.5-8.5$
\end{tabular}

- The ash generated at the bottom of 'Borma' air heater as well as the Steam Boiler and excess ash from initial firing of the roasting drum, have to be properly land filled with necessary precautions so that there are no secondary air emissions

- The cashew shell or de-oiled cake should not be sold to retail users for domestic and commercial firing purposes due to their obnoxious odor

Cashew nut industry-new and relocation-sitting criteria: Even though the pollutant emission load in to environment by a single cashew nut unit is low, it has been observed that the total emissions load by number of such units in a cluster causes considerable environmental degradation. To avoid the combined effect by number of units on the environment, the cashew nut processing industries with roasting/cooking process have to be located with the following criteria:

- Cashew Seed Processing Industry shall be established at least $1.0 \mathrm{~km}$ away from residential area, hospital, schools, public building or a place where flammable substances are stores/processed

- Cashew Seed Processing Industry shall be established $5.0 \mathrm{~km}$ away from notified municipal limits of any town/city or airport

- Cashew Seed Processing Industry shall not be constructed within $200 \mathrm{~m}$ from the middle of Railway Tracks, National Highway and State Highway and $50 \mathrm{~m}$ from the middle of other roads.

- In normal circumstances, installation of new cashew seed processing industry shall not be allowed in sensitive areas notified by the State Pollution Control Boards/Pollution Control Committees under the provisions of the National Air Quality Guidelines using coal as fuel
- The distance between two Cashew Seed Processing Industry shall not be less than $500 \mathrm{~m}$ to avoid clustering of Cashew Seed Processing Industry in an area if a new Cashew Seed Processing industry is being installed

\section{CONCLUSION}

India is largest producer, processor, exporter and second largest consumer of cashew in the world. Since cashew processing industries are small and cottage category units and no conventional and technoeconomically cost effective pollution abatement systems are in operation elsewhere, it has become necessary to study the entire cashew nut processing industry sector in India to suggest techno-economically feasible environmental standards. Even though the pollutant emission load in to environment by a single cashew nut unit is low, it has been observed that the total emissions load by number of such units in a cluster causes considerable environmental degradation. The cashew nut processing by cooking (steam roasting) process, which is relatively less pollution intensive and an alternative process to roasting process may be considered to reduce the environmental discharge load.

\section{REFERENCES}

Anonymous, 2006. Comprehensive industrial document and environmental standards for cashew seed processing industries. Central Pollution Control Board.

Anonymous, 2008. Statistical information. Directorate of Cashew and Cocoa Development.

Balasubramanian, D., 2007. Optimization of processing parameters using farm level cashewnut processing. J. Agric. Eng. Today, 32: 35-41.

Balsubramanian, D., 2006. Improving whole kernel recovery in cashew nut processing specific to Nigerian nuts. J. Mech. Asia, Africa Latin Am., 37: 58-64.

Smith, N.J.H., J.T. William, D.L. Plucknett and J.P. Talbot, 1992. Tropical Forests and their Crops. Paper Edn., Comstock Publishing, New York, ISBN: 10: 0801480582, pp: 568. 